\section{Cardiovascular effects induced by the aque- ous fraction of the ethanol extract of the stem of Solanum stipulaceum in rats.}

\author{
E.A.N. Ribeiro1; M.C.P. Batitucci²; J.A.T. Lima1; I.G.A. Araújo1; \\ H. Mauad²; I.A. Medeiros ${ }^{1 *}$
}

${ }^{1}$ Laboratório de Tecnologia Farmacêutica, Universidade Federal da Paraíba, CP 5009, 58051-970, João Pessoa, PB ${ }^{2}$ Departamento de Ciências Fisiológicas, Universidade Federal do Espírito Santo, Vitória, ES, Brazil

isacmed@uol.com.br

\begin{abstract}
The cardiovascular effects induced by the aqueous fraction of the ethanol extract of the stem (AFS) of Solanum stipulaceum Roem. \& Schult were studied in rats. In non-anesthetized rats, AFS injections produced significant and dosedependent hypotension associated with increase in heart rate. In isolated rat superior mesenteric rings, AFS was able to antagonize the contractions induced by phenylephrine and $\mathrm{KCl}$. The vasorelaxant activity of AFS was not inhibited by either removal of vascular endothelium, L-NAME, atropine or indomethacine. In isolated rat atrial preparations, AFS produced concentration-related negative inotropic and chronotropic responses. These results suggest that the hypotensive effect of AFS is due to a peripheral vasodilation, which can not be attributed to the participation of vascular endothelium. Finally, AFS acts directly on the heart decreasing contractility and heart rate.
\end{abstract}

The genus Solanum is the largest of the Solanaceae family comprising more than 1000 species which are widely distributed throughout the world in diverses habitats, from herbs to trees $^{1}$. It is well reported in the literature that plants of Solanaceae family produce significant hypotensive response in rabbits ( $S$. aculeastrum, $S$. adoense $)^{2}$ and in rats ( $S$. nigrum, $S$. ilicifolium, S. paniculatum, S. melongena $)^{3,4}$. In Paraíba state, the distribution of plants of Solanaceae family is abundant, however, just $S$. paludosum has been investigated about botanical, chemical and pharmacological aspects ${ }^{5}$. S. stipulaceum Roem. \& Schult. is a plant belonging to Solanaceae family, popularly known as jurubeba and its ethnomedicinal effects are unknown. A phytochemical screening of the crude extract of the stem of S. stipulaceum, demonstrated the presence of triterpenes/steroids, saponins and alkaloids. In the present work we attempted to characterize the cardiovascular effects induced by AFS in rats.

\section{Material and Methods}

Male Wistar rats (300-350 g) were used for all experiments. Animals were housed under conditions of controlled temperature $\left(21 \pm 1^{\circ} \mathrm{C}\right)$ and lighting (lights on: 06:00-18:00 h). The plant was collected in july 1999 (voucher specimen deposited in the Herbarium Prof. Lauro Pires Xavier, code Agra 5515) from the municipality of Serra Branca, state of Paraíba. The stems were separated, dried at $40{ }^{\circ} \mathrm{C}$ in an oven and pulverized. The powder was extracted with $70 \%$ ethanol/water at room temperature for $72 \mathrm{~h}$. The resulting extract was dried at $60{ }^{\circ} \mathrm{C}$ using a rotavaporator. When required, the extract was dissolved in water and filtered.

For measurement of arterial blood pressure and heart rate, we used the technique described by Oliveira et al., $1996^{6}$. Superior mesenteric artery rings were isolated according to the technique described by Tanaka et al., 19997. The presence of the endothelium was assessed by the ability of acetylcholine to induce more than $50 \%$ relaxation of vessels pre-contracted with phenylephrine. Rat atria were isolated according to Nasa et al., $1992^{8}$. Cumulative concentration-response curves were obtained

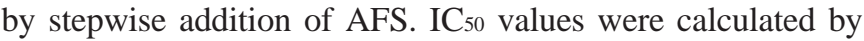
linear regression of individual concentration-response curves. Values are expressed as mean \pm s.e.mean. Statistical analysis were performed by means of paired Student's $t$-test when appropriate. Linear regressions were done by the least square method.

In 14 conscious rats, baseline values of mean arterial pressure and heart rate were $111 \pm 1 \mathrm{mmHg}$ and $366 \pm 7 \mathrm{bpm}$, respectively. AFS produced significant and dose-dependent hypotension associated with increase in the heart rate (Figure 1). To test the hypothesis that AFS acts directly on resistance vessels, we used the model of small mesenteric arteries ${ }^{7}$. In this preparation, AFS $(1,10,50,100,300,500 \mathrm{mg} / \mathrm{ml})$ antagonized, in a significant and concentration-dependent manner, phenylephrine $(10 \mathrm{mM})$ and $\mathrm{KCl}(80 \mathrm{mM})$ induced contractions with similar potency ( $\mathrm{IC}_{50}=138 \pm 10$ and $160 \pm 20 \mathrm{mg} / \mathrm{ml}$, respectively). It is well known that the maintenance of smooth muscle contraction depends upon $\mathrm{Ca}^{2+}$ entry from extracellular space through voltage (VOCC'S) and/or receptor operated (ROCC'S) calcium channels ${ }^{9,10}$. It is well known that $\mathrm{KCl}$ induces smooth muscle contraction through activation of VOCCs and subsequent release of calcium from the sarcoplasmic reticulum ${ }^{8,11}$ without changing other signal transduction systems including phosphatidylinositol turnover and calcium sensitization ${ }^{10}$. Considering that the contractions induced by $\mathrm{KCl}$ were inhibited in a concentration-dependent manner by AFS, it is reasonable to suggest that this extract block VOCC's. On the other hand, it is well established that NO is a major endothelium-derived relaxing factor, both in vivo and in vitro ${ }^{12}$. The release of NO from endothelial cells leads to relaxation of vascular smooth muscle cells, which plays a critical role in the maintenance of vascular tone ${ }^{12,13}$. To determine whether part of the relaxant effect produced by AFS in isolated superior mesenteric artery could be 
due to NO release, we performed experiments in superior mesenteric artery preparations in which the endothelium was mechanically removed or in preparations where the rings were preincubated with L-NAME $(100 \mathrm{mM})$, a competitive inhibitor of NO-synthase ${ }^{13}$. Under these conditions, AFS-induced smooth muscle relaxation was not attenuated (Figure 2), indicating that relaxing factors released by the endothelium, mostly NO, do not play an important role in the vasorelaxant response induced by AFS. Furthermore, the vasorelaxant effect of AFS was unaffected by indomethacine or atropine (Figure 2), which allowed us to definitely rule out the participation of relaxant factors released by the vascular endothelium. Finally, to investigate an additional direct cardiac action of AFS we designed experiments on isolated atrial preparations. In these preparations, AFS induced negative inotropic and chronotropic effects (IC50 $=516 \pm 48$ and $493 \pm 55 \mathrm{mg} / \mathrm{ml}$, respectively).

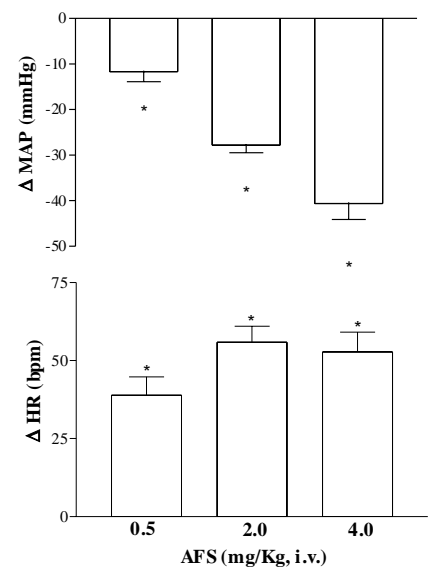

Figure 1. Bar graphs show peak changes in mean arterial pressure (MAP), and heart rate (HR) induced by the acute administration of increasing doses of AFS $(0.5,2$ and $4 \mathrm{mg} / \mathrm{kg}$, i.v.) in conscious unrestrained normotensive rats. Results are means \pm s.e.m. $(\mathrm{n}=14)$. $* \mathrm{p}<0.05$ vs saline.
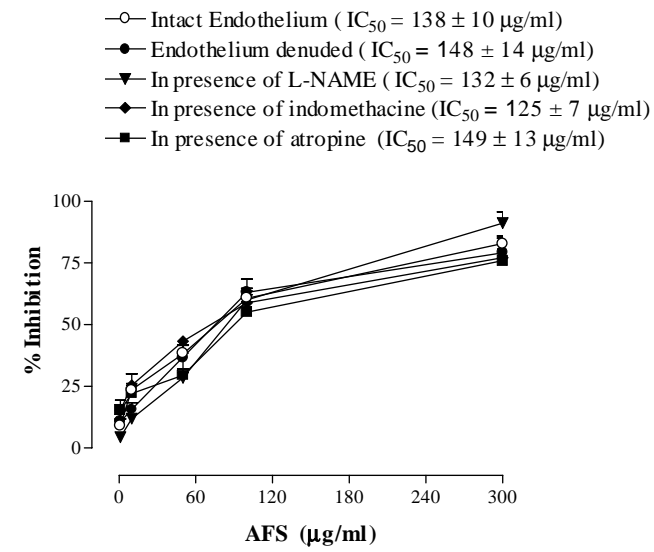

Figure 2. Line plot graph showing the effects of AFS on isolated rat superior mesenteric artery rings pre-contracted with phenylephrine $(10 \mu \mathrm{M})$, with intact endothelium, endothelium denuded, pre-incubated with $1 \mathrm{mM}$ atropine and after $100 \mu \mathrm{ML}$ NAME. Values are mean \pm s.e.m. $(n=7$, each group).
In conclusion, the present study, using combined in vivo and in vitro studies, demonstrates that AFS lowers arterial pressure in rats through a decrease in peripheral vascular resistance, without the participation of endothelial cells. AFS exhibits direct cardiac-depressant properties.

\section{References}

${ }^{1}$ D'Arcy WG. The solanaceae since 1976 with a review of its biogeography. In: J.G. Hawkes, R.N. Lester, M. ee \& N. EstradaR., editors, Solanaceae III: Taxonomy, Chemistry, Evolution, Royal Botanic Gardens Kew, 1991: 75-137

${ }^{2}$ Chagnon M. General pharmacologic inventory of medicinal plants of rwanda. Journal of Ethnopharmacology 1984; 12 (3): 239-51

${ }^{3}$ Dhar ML, Dhar MM, Dhawan BN, Mehrotra BN, Ray C. Screening of indian plants for biological activity: Part I. Indian Journal of Experimental Biology 1968; 6: 232-47

${ }^{4}$ Adesina SK. Studies on some plants used as anticonvulsants in amerindian and african traditional medicine. Fitoterapia 1982; 53: $147-62$

${ }^{5}$ Ataíde JR. Atividade farmacológica dos extratos da jurubeba roxa Solanum paludosum Moric. In: Dissertação de mestrado do curso de pós-graduação em produtos naturais (farmacologia e química) / UFPB, João Pessoa, 1982

${ }^{6}$ Oliveira EJ, Medeiros IA, Mukeierjee R. Hypotensive and spasmolytic effects of normacusine B from Strychnos atlantica root. Phytomedicine 1996; 3: 45-49

${ }^{7}$ Tanaka Y, Mochizuki Y, Tanaka H, Shigenobu K. Significant role of neuronal non-N-type calcium channels in the sympathetic neurogenic contraction of rat mesenteric artery. British Journal of Pharmacology 1999; 128: 1602-8

${ }^{8}$ Nasa Y, Ichihara K, Yoshida R, Abiko Y. Positive inotropic and negative chronotropic effects of (-)-cis-diltiazem in rat isolated atria. British Journal of Pharmacology 1992; 105 (3): 696-702

${ }^{9}$ Nelson MT, Patlak JB, Worley JF, Standen NB. Calcium channels, potassium channels, and voltage dependence of arterial smooth muscle tone. American Journal of Physiology 1990; 259 (1 Pt 1): C3-C18

${ }^{10}$ Karaki H, Ozaki H, Hori M, Mitsui-Saito M, Amano K, Harada K, Miyamoto S, Nakazawa H, Won KJ, Sato K. Calcium movements, distribution, and functions in smooth muscle. Pharmacological Reviews 1997; 49 (2):157-230

${ }^{11}$ Gurney AM. Mechanisms of drugs-induced vasodilatation. Journal of Pharmacy and Pharmacology 1994; 46 (4): 242-251

${ }^{12}$ Moncada S, Palmer RMJ, Higgs EA. Nitric oxide: Physiology, pathophysiology and pharmacology. Pharmacological Reviews 1991; 43: 109-42

${ }^{13}$ Moncada S, Higgs EA. The L-arginine-nitric oxide pathway. New England Journal of Medicine 1993; 29: 2002-12 